\title{
Çalışanların Algıladıkları Örgütsel Desteğin Psikolojik Sahiplenme Üzerine Etkisi
}

\author{
DOI: $10.26466 /$ opus.658193
}

\author{
* \\ Gül Çıkmaz ${ }^{*}$ Salih Yeşil ${ }^{* *}$ \\ * Doktora öğr., Hasan Kalyoncu Üniversitesi, İ̈BF., Gaziantep/Türkiye \\ E-Posta: gul.ckmz@gmail.com \\ ORCID: 0000-0002-3973-2984 \\ ** Prof. Dr. Kahramanmaraş Sütçü İmam Üniversitesi, İ̈BF, Kahramanmaraş/Türkiye \\ E-Posta : syes66@hotmail.com \\ ORCID: 0000-0003-3237-2258
}

\begin{abstract}
Öz
Bu çalışma örgütsel destek ve psikolojik sahiplenme konularmı ele almakta ve incelemektedir. Çalışmanın amacı, örgütsel bağlamda ortaya çıkan örgütsel destek olgusunun psikolojik sahiplenme ile ilişkisi ve üzerinde etkisinin olup olmadığını belirlemektir. Araştırma bir alan çalışması içermektedir. Araştırmanın çalışma grubunu Gaziantep ilinde KOBİ niteliğinde çalı̧̧an işletmelerde görev yapan toplam 326 çalışan oluşturmaktadır. Çalışmada veriler anket soru formu yardımıyla toplanmıştır. Elde edilen verilerin istatistiki analizi için SPSS 21.0 kullanılmıştır. Çalışma sonucunda algılanan örgütsel destek ile psikolojik sahiplenme arasında negatif yönlü anlamlı bir ilişki olduğu belirlenmiştir. Ayrica algilanan örgütsel desteğin psikolojik sahiplenme üzerinde negatif yönlü bir etkiye sahip olduğu ortaya çıkmıştır. Elde edilen sonuçlar, örgütsel destek ve psikolojik sahiplenme arasındaki ilişkileri ortaya koymak açısından önem taşımaktadır. Örgütsel destek algılamalarının, psikolojik sahiplenme üzerindeki etkisinin araştırıldığı bu çalışmada, örgütsel destek davranışların da ortaya çıkan olumsuz algılamalarm, psikolojik sahiplenme duygusuna yönelik algilamalar negatif yönde etkileyebileceği belirlenmiştir. Bu sonuçlar gerek teorik ve gerekse uygulama perspektiflerinden sonuç kısmında tartışılmıştır.
\end{abstract}

Anahtar Kelimeler: Sahiplenme, Psikolojik Sahiplenme, Algılanan Örgütsel Destek. 


\title{
The Effect of Perceived Organizational Support on Psychological Ownership
}

\begin{abstract}
The purpose of this study is to investigate whether organizational support has an effect on psychological ownership perception. Method: A total of 326 employees working in the SME in Gaziantep were the sample of this study. Data wascollected through survey method and subsequently collected data were staticially analysed by using SPSS 21.0. Results: According to the findings, there was a negative relationship between organizational support and psychological ownership perceptions. In addition, perceived organizational support had a negative effect on psychological ownership. Discussion: In this study where the effects of organizational support perceptions on psychological ownership were examined, it was seen that negative perceptions in organizational support behaviors could affect perceptions of psychological ownership negatively. This study focuses on and investigates the organizational support and psychological ownership perception. The purpose of this study is to investigate whether organizational support has an effect on psychological ownership perception. The study involved a field research. A total of 326 employees working in the SME in Gaziantep comprised the sample of this study. Data was collected through survey method and subsequently collected data were statically analyzed by using SPSS 21.0. According to the findings, there was a negative relationship between organizational support and psychological ownership perceptions. In addition, perceived organizational support had a negative effect on psychological ownership. The results were important to reflect upon the relationship between organizational support and psychological ownership perception. In this study where the effects of organizational support perceptions on psychological ownership were examined, it was seen that negative perceptions in organizational support behaviors could affect perceptions of psychological ownership negatively. The findings were discussed from the perspectives of both theory and practice.
\end{abstract}

Keywords: Ownership, PsychologicalOwnership, Perceived Organizational Support 


\section{Giriş}

İnsanlar, duygu, düşünce ve davranış üçleminde yaşayan sosyal varlıklardır. İnsanların nesne ve olgular karşısında hissettikleri duygular, düşüncelerini, bu iki olgunun birleşimi ise davranışları meydana getirmektedir. İnsanlık tarihinin bugünlere gelmesinde öncelikli bir duygu vardır ve bu duygu istisnasız her insanın doğuştan sahip olduğu bir duygudur. Bu duyguya "sahiplenme duygusu" adı verilmiştir. Sonsuz ve sınırsız ihtiyaçlar çerçevesinde hayatı boyunca sahip olmadıklarına sahip olmaya çalışan insanların hayat hikâyeleri aynı zamanda insanlık tarihinin de hikâyesidir.

Sahip olma duygusu, insanların tabiatında vardır. Bu olgu sadece sosyal hayatta değil, çalışma hayatında da yer almaktadır. Bu durumun farkında olan işletmeler ise, çalışanların çalıştıkları kurumu kendi işyerleri gibi benimsemesi ve sahiplenebilmeleri adına birçok çalışmalar yapmaktadır. Jeswani ve Dave (2012)'e göre şirketler, insanların soyut veya somut varlıklara karşı hissettikleri sahiplenme duygusundan hareketle, maddi veya manevi bireysel veya örgütsel hedeflerle bağlantı kurulabileceği yönünde çalışmalar üzerinde yoğunlaşmıştır.

Örgütsel destek, 1980'li yıllarda ön plana çıkmış bir konudur. Bu kavram çalışanların örgütlerine yapmış olduğu katkının, örgüt tarafından önemli görülmesi ve örgütün çalışanlarına değer vermesi ve bunun çalışanlar tarafından algılanması ile ortaya çıkmıştır (Hellman Fuqua ve Worley, 2006, s.631).

$\mathrm{Bu}$ çalışmada, algılanan örgütsel desteğin psikolojik sahiplenme ile ilişkisi ve üzerindeki etkisi incelemiştir. Genel olarak örgütsel destek "terfi, iş zenginleştirme, ödül, örgütsel politikalar, etkileşimi, performans" "adalet" gibi birçok kavramla ilişkilendirilmiştir fakat şu ana kadar, psikolojik sahiplenme üzerinde etkisi olup olmadığına ilişkin yapılan çok çalışmaya rastalanılmamıştır. Litaratür incelendiğinde psikolojik sahiplenmenin genel sonuçlarıyla ilgili çalışmalar olsa da (Van Dyne ve Pierce, 2004), daha önce konuyla ilgili yapılan araştırmalar sınırlı kalmıştır (Ötken, 2015, s.115). Bu nedenle bu iki kavram arasında ilişki ve etkinin olup olmadığını ortaya koymanın, kavramların daha iyi anlaşılması ve ilgili yazına katkıda bulunmak açısından önem taşımaktadır. Bu bağlamda 
bir alan çalışması yapılmış olup ve algılanan örgütsel destek ile psikolojik sahiplenme arasındaki ilişki ve üzerindeki etkisi belirlenmeye çalışılmıştır.

Çalışma sırasıyla kuramsal çerçeve, yöntem, analiz sonuçları ve sonuç bölümleri olarak şekillenmiştir.

\section{Algılanan Örgütsel Destek}

Blau (1964)'a göre algılanan örgütsel destek kavramının tanımlanmasında, "Sosyal Değişim Teorisi" ön plana çıkmaktadır (Eisenberger, Huntington, Hutchison ve Sowa, 1986, s.500; Rhoades ve Eisenberger, 2002, s.698). Örgütsel destek teorisine göre, algılanan örgütsel destek kavramının gelişimi çalışanların kurumdaki çalışanlara insani özellikler gösterme eğilimi ile onları teşvik etmesiyle ortaya çıkmıştır (Eisenberger, Huntington, Hutchison ve Sowa, 1986, s.500). Araştırmacılar, birey ve örgüt arasındaki ilişkileri anlamak için giderek daha fazla sosyal değişimi teorik bir temel olarak benimsemişlerdir. Blau (1964), sosyal değişimin, bir bireyin bir başkasına bir iyilik yapması durumunda belirtilmeyen yükümlülükler getirdiğini, gelecekteki bir geri dönüş beklentisinin olduğunu ifade eder (Coyle-Shapiro ve Conway, 2005, s.775). Blau (1964)'nun sosyal değişim teorisi, çalışanlar ile örgütler arasında var olan ama kesin bir şekilde tanımlanmayan, uyulmadığı zaman önemli olumsuz sonuçlar doğuracağını, karşılıklı zorunluluklar olduğunu söylemektedir (Coyle-Shapiro ve Conway, 2005, s.777).

Eisenberger (1986) en genel anlamıla örgütsel desteği “örgütün çalışanın katılımına önem vermesi, iyiliğini önemsemesi ve çalışanları etkileyen faaliyetlerin örgütün gönüllü olarak gerçekleştirdiğine ilişkin duyguları" şeklinde tanımlamıştır. Şimdiye kadar yapılan araştırmalarda algılanan örgütsel destek; çalışanların katkısına değer vermeye, mutluluğunu önemsemeye ve ihtiyaçlarını karşılamaya yönelik algılar olarak ifade edilmektedir (Kerse ve Karabey, 2017, s.379).

Bir örgütte çalışanların örgütsel destek algıları, çalışanların işe ve işletmeye karşı tutumlarını etkileyebilmektedir. İnsanlar başkaları tarafından desteklendiğini algılaması kendini iyi hissetmesine neden olmaktadır. Bu bağlamda bir çalışanın kurumu tarafından desteklendiğini hissetmesi önemlidir. Desteğin hem kurum hem de çalışanlar açısından önemi büyüktür (Giray ve Şahin, 2013, s.2). Çakır (2001), örgütsel desteğin, 
günümüz çalışanlarının önemli haklarından biri haline gelmeye başladığını ifade etmiştir. Toplam kalite yönetimi, personel güçlendirme, mükemmellik yaklaşımı gibi yeni yönetim araçları ve sistemleri, örgütteki çalışanların önemsenmesini zorunlu kılmaktadır. Çalışanların fikirlerinin önemsenmesi ve her konuda destek olunması ve bunu hissetmeleri çalışma performanslarını daha da artıracaktır. Algılanan örgütsel destek sosyo-duygusal ihtiyaçları karşılayan performans-ödül beklentilerini artırarak ve gerektiğinde yardımda bulunup genel iş tatminine katkıda bulunmaktır ((George, Mood ve Absence 1989, s.319). Sosyal Değişim Kuramı'na göre, örgütler; çalışanlarının mutluluğu artırmak için yetkinlik ve değer duygularına katkıda bulunarak faaliyetler yapmaları ve çalışanların yapılan faaliyetleri zamanında ve doğru algılamalarını başardıkları zaman çalışanların ruh hali gelişmekte ve böylelikle sosyal değişimin sürekliliği sağlamış olmaktadır (Rhoades ve Eisenberger, 2002, s.701).

\section{Psikolojik Sahiplenme}

Psikolojik sahiplenme kavramı zihinsel bir durum olarak, bireylerin sahiplenme hedefi veya onun bir parçası gibi hissettiği durum yani kurumun "kendilerinin" gibi hissettiği durum şeklinde tanımlanır. Psikolojik sahiplenmenin özü, sahiplenme ve psikolojik olarak bir nesneye bir şeye bağlı olma hissi (Pare, Sicotte ve Jacque 2006, s.198), bir nesneyi, varlığ veya fikri "benim" veya "bizim" olduğunu düşünmektir (Furby, 1991, s. 458). Pierce, Kostova ve Dirks (2001), psikolojik sahiplenmeyi hem duygusal hem de bilişsel unsurlara karşı bir tutum olarak tanımlamışlardır.

Psikolojik sahiplik, bir çalışanın hedeflerine ulaşmak için için olumlu hisler geliştirdiği psikolojik olarak deneyimli bir olgudur (Van Dyne ve Pierce, 2004:, s.442; Pierce vd., 2001, s.299), kişilerin nesneleri kendininmiş gibi hissetmelerini psikolojik sahiplik olarak ifade ederlerken, çalışanın örgütü kendisininmiş gibi hissettiği durumları da çalışanların örgütü psikolojik olarak sahiplenmeleri olarak göstermektedirler.

Çalışanların psikolojik sahipliği, kısmen firmanın salt bilişsel değerlendirmesini aşan kuruma duygusal bir bağl1lı̆̆ıdır, bu duygu, firmaya gruba olabileceği gibi ekipmanlara yani iş araçlarına da olabilmektedir. Sahiplenmenin faklı amaçları vardır ve bunlar bireye ve duruma bağlı olarak değişebilir. Örneğin, bazı çalışanların sadece çalıştıkları kuruma 
karşı psikolojik sahipliği var, bazılarının ise tüm kurum için yani kuruma ait tüm ne varsa onlar için de sahiplenme duygularına sahip olabilirler (Van Dyne ve Pierce, 2004, s.442).

Örgüt için psikolojik sahiplik, kişinin “Bu kuruluş (iş yeri)'un ne kadar benim olduğunu hissediyorum?" sorusuna cevap iken, örgütsel bağlllık ise "Bu iş yerinde çalışmamı neden sürdürmeliyim?" sorusuna cevaptır (Meyer ve Allen, 1991, s.63). Kuruluşa sahip olma hissini yani kuruluşun kendininmiş gibi sahiplenme hissi, kuruluşta kalma arzusu, ihtiyacı veya yükümlülüğünü ifade eden örgütsel bağlllıktan hissetmekten farklıdır (Meyer ve Allen, 1997, s.62).

Literatürde psikolojik sahiplenmenin üç nedene bağlı olarak ortaya çıktığı ifade edilmektedir. Birincisi kurumun çalışana kendini daha iyi ve etkili hissetmesine neden olacak fırsatlar sunmasıdır. Bireyler çevrelerinin kontrolünde olduklarını düşündüklerinde, kendilerini daha etkin hissedecek ve mutluluk duyguları ortaya çıkacaktır (Pierce, vd. 2003, s.90). Diğer bir neden, çalışanların kendilerini tanımlamak amacıyla sahiplik hissettikleri örgütün bir parçası haline gelmesidir (McIntyre, Srivastava ve Fuller, 2009, s.384). Bireyin kuruma olan iletişim ve etkileşimden keyif duydukça kendini iyi hissettikçe, örgütün bireyin kişiliğinin bir parçası haline geldiği söylenebilir. Diğer taraftan çalışan kendi değerleriyle örgütün değerlerinin birbiriyle uyumlu olduğunu hissettiğinde, o örgütteki üyeliğini devam ettirmek isteyecek ve örgüte bağlı hissedecektir (Ötken, 2015, s.118). Psikolojik sahiplenme nedenlerinden üçüncüsü ise çalışanın kendine ait bir yer edinme arzusunu yerine getirmesi ve kurumda kendi evindeymiş gibi hissetmesidir (White, 1959). Pierce vd. (2003)'e göre, bu durum çalıştıkları kuruma çok fazla duygusal yatırım yapan ve kendilerini kurumlarıyla özdeşleştiren çalışanlarda daha fazla olmaktadır. Çalışanların kurumlarında geçirdikleri zaman dikkate alındığında, kurumu evleri gibi hissetmeleri normal olup ve kısmen de olsa yaşanacak yer ihtiyaçlarını tatmin edecektir. Yukarıda açıklanan bu üç nedenin karşılanması çalışan ve örgüt için önemlidir. Bu üç nedenin de karşılanması durumunda çalışan bireyin psikolojik sahiplik algısı artabilecektir (Ötken, 2015, s.118).

Örgütüne sahiplenen bireyler işyerinde daha yüksek performans sergileyeceklerdir. İş yerini sahiplenen çalışanların işe devamsızlıkları, geç kalmaları ve işten ayrılma gibi davranışlarında azalmalara sebep olacaktır (Mathieu ve Zajac, 1990, s.187). Yapılan araştırmalarda psikolojik sa- 
hiplenmenin en önemli sebeplerinden birinin örgütsel destek olduğu görülmektedir.

\section{Yöntem}

$\mathrm{Bu}$ çalışmada amaç, algılanan örgütsel desteğin çalışanların psikolojik sahiplenmesi ile ilişkisini ve üzerindeki etkisini belirlemektir. Araştırmanın amacını gerçekleştirmek için bir alan çalışması yapılmıştır. Araştırmada veri toplama yöntemi olarak anket kullanılmıştır. Veriler anket soru formu vasıtasıyla çalışanlardan toplanmıştır. Veriler SPSS istatistik programinda frekans, korelasyon ve regresyon analizlerine tabi tutularak sonuçlara ulaşılmıştır.

\section{Evren ve Örneklem}

Araştırmanın evrenini, Gaziantep Organize Sanayi Bölgesinde faaliyet gösteren küçük ve orta ölçekli şirket çalışanları oluşturmaktadır. Araştırmada anketler firmalara gidilerek dağıtılmaya ve toplanmaya çalışmıştır. Yaklaşı 100 civarında firmaya gidilmiş ve 1000 adet anket dağ1tılmıştır. Toplamda 353 anket formu cevaplanmış olarak araştırmacılara ulaşmıştır. Geri dönüşs sağlanan anketlerden ise, eksik/hatalı 27 anket formu değerlendirilmeye alınmamış olup, toplam 326 anket formu analizlerde kullanılmıştır.

\section{Araştırma Modeli ve Hipotezler}

Araştırmanın amaçları doğrultusunda oluşturulan ve test edilmek istenilen hipotezler aşağıda sunulmuştur:

- H1: Örgütsel destek ve alt bileşenleri ile psikolojik sahiplenme arasında pozitif yönlü bir ilişki vardır

- H2: Örgütsel destek ve alt bileşenlerinin psikolojik sahiplenme üzerinde pozitif yönde bir etkisi vardır

Araştırma çerçevesinde oluşturulan model şekil 1'de sunulmuştur. 


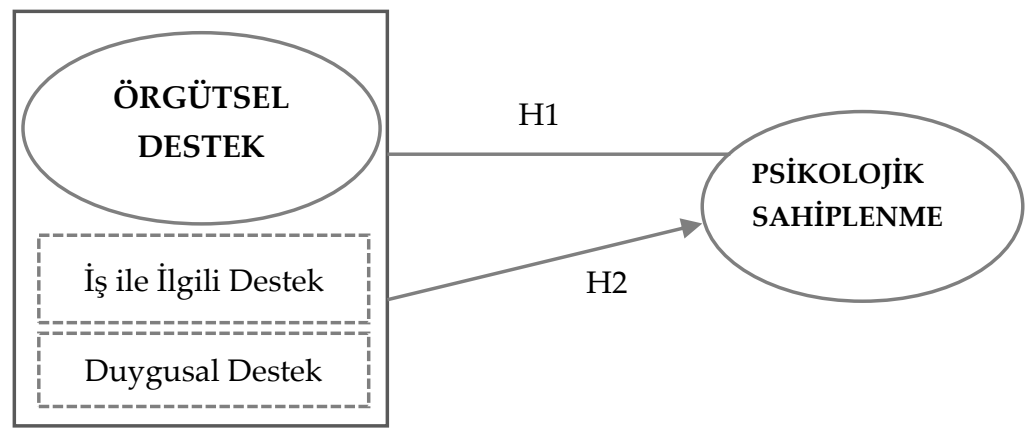

Şekil 1. Araştırma Modeli

\section{Verilerin Toplanmast}

Araştırmada daha önce literatürde sıklıkla kullanılan ve güvenilirlik ve geçerliliği kabul edilmiş ölçekler kullanılmaya çalışılmıştır.

Psikolojik Sahiplenme Ölçeği an Dyne ve Pierce (2004) tarafından geliştirilen 8 soru önermesinden oluşan "Psikolojik Sahiplenme Ölçeği" kullanılmıştır. Algılanan Örgütsel Destek Ölçeği Eisenberger (1986) tarafından oluşturulan 8 soru önermesine sahip olan "algılanan örgütsel destek" ölçeğidir. Söz konusu ölçekte 1-4 arasında yer alan soru önermeleri "iş ile ilgili destek" boyutunu ve 5-8 arasında yer alan soru önermeleri ise "duygusal destek" boyutunu oluşturmuştur. Ölçek soru önermeleri 5'li likert yöntemi ile hazırlanmıştır Örgütsel destek alt boyutlarının güvenirlilik derecelerinin sırası ile 669 ve682 olduğu tespit edilmiştir.

Çalışmada ayrıca katılımcıların demografik özelliklerini yönelik "yaş, eğitim, cinsiyet, medeni durum, alınan maaş, sahip olunan pozisyon ve çalışma süresi" gibi yedi soru sorulmuştur.

\section{Bulgular}

\section{Demografik bulgular}

Katılımcıların demografik açıdan özellikleri frekans analizi yoluyla belirlenmiş ve aşağıdaki tablolarda detaylı olarak sunulmuştur. 
Tablo 1. Katılımcıların yaşlarına göre dă̆ılımı

\begin{tabular}{lcc}
\hline Yaş & $\mathbf{N}$ & \% \\
\hline 20 ve altı & 53 & 16,3 \\
$26-30$ & 83 & 25,5 \\
$31-35$ & 82 & 25,2 \\
$36-40$ & 77 & 23,6 \\
41 ve üstü & 31 & 9,5 \\
Toplam & 326 & 100,0 \\
\hline
\end{tabular}

Tablo 2. Cinsiyete göre adayların eğitim durumuna ilişkin dağılım.

\begin{tabular}{lcc}
\hline Cinsiyet & N & \% \\
\hline Kadın & 60 & 18,4 \\
Erkek & 266 & 81,6 \\
\hline
\end{tabular}

Tablo 3. Eğitim duurmlarına göre adaylarn ilişkin dă̆ılım

\begin{tabular}{lcc}
\hline Eğitim & N & $\%$ \\
\hline Orta Ö̆ğretim & 127 & 39 \\
Lise & 82 & 25,2 \\
Ön Lisans & 50 & 15,3 \\
Lisans & 60 & 18,4 \\
Lisansüstü & 6 & 1,8 \\
\hline
\end{tabular}

Tablo 4. Medeni durumlarına göre ilişkin dağılım.

\begin{tabular}{lcc}
\hline Medeni Durum & N & \% \\
\hline Evli & 227 & 69,6 \\
Bekar & 99 & 30,4 \\
\hline
\end{tabular}

Tablo 5. Katılımcıların yaşlarına göre dă̆ılımı

\begin{tabular}{|c|c|c|}
\hline Çalışma Süresi & $\mathbf{N}$ & $\%$ \\
\hline 1 Ay - 3 yil & 121 & 37,1 \\
\hline 3-6 Yil & 87 & 26,7 \\
\hline 6-9 Y 11 & 55 & 16,9 \\
\hline 9-12 Y1l & 32 & 9,8 \\
\hline $12-15 Y_{11}$ & 19 & 5,8 \\
\hline $15 \mathrm{Y}_{11}+$ & 12 & 3,7 \\
\hline
\end{tabular}

Tablo 6. Pozisyon durumlarına gore dağılım.

\begin{tabular}{lcc}
\hline Pozisyon & N & \% \\
\hline Üst düzey yönetici & 18 & 5,5 \\
Orta düzey yönetici & 65 & 19,9 \\
Alt düzey yönetici & 75 & 23 \\
Yönetim görevim yok & 168 & 51,5 \\
\hline
\end{tabular}


Tablo 7. Aylık gelir durumlarına gore dağılım.

\begin{tabular}{lcc}
\hline Gelir & $\mathbf{N}$ & \% \\
\hline $0-1.500 \mathrm{TL}$ & 107 & 32,8 \\
$1.501-3.000 \mathrm{TL}$ & 139 & 42,6 \\
$3.001-4.500 \mathrm{TL}$ & 64 & 19,6 \\
$4.501-6.000 \mathrm{TL}$ & 8 & 2,5 \\
6.001 TL ve üzeri & 7 & 2,1 \\
\hline
\end{tabular}

Katılımcıların yaş dağılımlarına bakıldığı zaman, çoğunluğunun 26-30, 31-35 ve 36-40 yaş gruplarında olduğu belirlenmiştir. Eğitim açısından demografik özelliklere bakıldığında, katılımcıların çoğunluğunun ortaöğretim düzeyine (\%39) sahip oldukları görülmektedir. Katılımcıların geri kalanının ise lise $(\% 25,2)$, lisans $(\% 18,4)$, ön lisans $(\% 15,3)$ ve lisansüstü $(\% 1,8)$ eğitim düzeylerine sahip oldukları görülmektedir. Medeni duruma açısından katılımcıların \%69,6'sının evli, \%30,4'ünün bekâr olduğu görülmüştür.

Katılımcıların cinsiyet dağılımlarına bakıldığında \%81,6'sının erkek, \%18,4'ü kadınlardan oluşmaktadır. Çalışma süresi bakımından en çok yığılmanın 1 ay ile 3 yıl arasında olduğu (\%37,1), en az yı̆̆ılmanın ise 15 yıl üstü $(\% 3,7)$ grubunda görüldüğü belirlenmiştir.Katılımcıların aylık geliri incelendiğinde, en çok yığılmanın 1.5001-3.000 TL ücret alanlarda, en az yığılmanın ise 6.001 TL ve üzeri alanlarda olduğu tespit edilmiştir. Son olarak katılımcların pozisyonu incelendiğinde en fazla yığılmanın yönetim görevi olmayanlarda olduğu $(51,5)$, en az yığılmanın ise üst düzey yönetici pozisyonunda olanların $(5,5)$ olduğunu söylemek mümkündür.

\section{Doğrulayıcı Faktör Analizi ve Güvenirlilik Sonuçları}

Araştırma kapsamında kullanılan örgütsel destek ölçeği iki boyutlu olup, sekiz önermeden oluşmaktadır. Yine 8 soru önermesinden oluşan, psikolojik sahiplenme ölçeği ise tek bir boyutta incelenmiştir. Ölçeklerin yapısal geçerliliği ve doğrulayıcı faktör analizlerini yapabilmek için verilerin uygun olup olmadığını tespit etmek amacıyla Kaiser Meyer Olkin katsayısı ve Bartlett Sphericity değerlerine bakılmıştır. Araştırma kapsamında kullanılmış olan ölçeklerin güvenirliliğini belirlemek için Cronbach's Alfa değerleri dikkate alınmıştır. 
Araştırmanın faktör ve güvenirlilik sonuçları Tablo 8 ve Tablo 9' da sunulmuştur.

Tablo 8 .Örgütsel Destek Ölçeği Doğrulayıcı Faktör Analizi ve Güvenirlilik Sonuçları

\begin{tabular}{llllll}
\hline Boyutlar & $\begin{array}{l}\text { Soru } \\
\text { Önermesi }\end{array}$ & $\begin{array}{l}\text { Açıllanan } \\
\text { Varyans }\end{array}$ & $\begin{array}{l}\text { Toplam } \\
\text { Varyans }\end{array}$ & $\begin{array}{l}\text { Cronbah's } \\
\text { Alpha }\end{array}$ & $\begin{array}{l}\text { Genel } \\
\text { Cronbach's Alpha }\end{array}$ \\
\hline İş ile İlgili Destek & $1-4$ & 41,655 & 75,684 &, 669 &, 634 \\
$\begin{array}{l}\text { Duygusal Destek } \\
\text { Kaiser Meyer }\end{array}$ & $5-8$ & 34,029 & &, 682 & \\
$\begin{array}{l}\text { Güvenirliliğek } \\
\text { Bartlett's Küresellik }\end{array}$ &, 679 & & & & \\
$\begin{array}{l}\text { Testi Ki-Kare } \\
\quad \text { Sd }\end{array}$ & 622,256 & & & & \\
P Değeri & 28 & & & & \\
\hline
\end{tabular}

Örgütsel destek ölçeği 8 soru önermesi olmakla birlikte 2, 3, 5 ve 7. sorular ters ifadelerden oluşmaktadır.

Örgütsel destek ve alt boyutlarına yönelik doğrulayıcı faktör analizi sonucunda iş ile ilgili destek alt boyutu önermelerinin faktör yükleri sırası ile $645 ;, 682 ;, 748$ ve 689 'dur. Aynı şekilde duygusal destek alt boyutunun faktör yükleri ise sırası ile 774; 643; 692 ve 689'dur. Ayrıca örgütsel destek ölçeğinin iki alt bileşeninin toplam varyansın \%75,7'sini açıkladığı görülmektedir. Genel kanı güvenilirliğin 0,70 üzerinde olmasıdır. Fakat Kalaycı (2014) çaışmasında 0,60 ve 0,70 arasındaki katsayıların güvenilir olduğunu belirtmiştir.

Algılanan örgütsel desteğin alt bileşenlerin güvenirlilik derecelerine bakıldığında; alt boyutlarının 669 ve 682 değerinde Cronbach's Alpha'ya sahip olduğu ve genel Cronbach's Alpha değerlerinin ise, 634 (KMO: ,679; Ki-Kare: 622,256; sd: 28; p:,000) olduğu belirlenmiştir.

Tablo 9. Psikolojik Sahiplenme Ölçeği Faktör Analizi ve Güvenirlilik Sonuçlam

\begin{tabular}{lll}
\hline Boyutlar & Soru Önermesi & Cronbach's Alpha \\
\hline Psikolojik Sahiplenme & 8 &, 783 \\
KaiserMeyer Ölçek Güvenirliliği &, 828 & \\
Bartlett's Küresellik Testi Ki-Kare & 779,673 & \\
Sd & 21 & \\
P Değeri &, 000 & \\
\hline
\end{tabular}


Doğrulayıcı faktör analizi sonucunda psikolojik sahiplenme ölçeğinin genel Cronbach's Alpha değerlerinin ,785 (KMO: ,828; Ki-Kare: 779,673; sd: $21 ; \mathrm{p}:, 000)$ olduğu belirlenmiştir. Sosyal bilimler açısından araştırmada kullanılan iki ölçeğin yeterli düzeyde geçerlilik düzeyine sahiptir.

Tablo 10. Doğrulayıcı Faktör Analizi Sonucunda Uyum İyiliği Değerleri

\begin{tabular}{|c|c|c|c|c|c|c|c|c|c|}
\hline Değişkenler & $X^{2}$ & $\mathrm{df}$ & $\begin{array}{l}\text { CMIN/ } \\
\text { DF } \leq 5\end{array}$ & $\begin{array}{l}\text { GFI } \\
\geq .85\end{array}$ & $\begin{array}{l}\text { AG } \\
\text { FI } \\
\geq .80\end{array}$ & $\begin{array}{l}\text { CFI } \\
\geq .90\end{array}$ & $\begin{array}{l}\text { NFI } \\
\geq .90\end{array}$ & $\begin{array}{l}\text { TLI } \\
\geq .90\end{array}$ & $\begin{array}{l}\text { RMSEA } \\
\leq .08\end{array}$ \\
\hline $\begin{array}{l}\text { Örgütsel } \\
\text { Destek }\end{array}$ & 16,70 & 11 & 2,341 & ,981 & ,938 & ,975 & ,959 & ,937 & ,064 \\
\hline $\begin{array}{l}\text { Psikolojik } \\
\text { Sahiplenme }\end{array}$ & 29,841 & 12 & 2,487 & ,975 & 943 & ,977 & ,92 & 959 & 068 \\
\hline
\end{tabular}

Not: Uyum iyiliği değer aralıkları "kabul edilebilir" standartlara göre düzenlenmiştir.

Tablo 10'da görüldügü gibi ölçeklerin uyum iyilik değerleri kabul edilebilir değerlerdedir.

Örgütsel destek ölçeği 8 soru önermesi olmakla birlikte 2, 3, 5 ve 7. sorular ters ifadelerden oluşmaktadır.

Örgütsel destek ve alt boyutlarına yönelik doğrulayıcı faktör analizi sonucunda iş ile ilgili destek alt boyutu önermelerinin faktör yükleri sırası ile $645 ;, 682 ;, 748$ ve 689 'dur. Aynı şekilde duygusal destek alt boyutunun faktör yükleri ise sırası ile 774; 643; 692 ve 689'dur. Ayrıca örgütsel destek ölçeğinin iki alt bileşeninin toplam varyansın \%75,7'sini açıkladığı görülmektedir.

Algılanan örgütsel desteğin alt bileşenlerin güvenirlilik derecelerine bakıldığında; alt boyutlarının 669 ve 682 değerinde Cronbach's Alpha'ya sahip olduğu ve genel Cronbach's Alpha değerlerinin ise ,634 (KMO: ,679; Ki-Kare: 622,256; sd: 28; p:,000) olduğu belirlenmiştir.

Tablo 11. Psikolojik Sahiplenme Ölçeği Faktör Analizi ve Güvenirlilik Sonuçlan

\begin{tabular}{lll}
\hline Boyutlar & Soru Önermesi & Cronbach's Alpha \\
\hline Psikolojik Sahiplenme & 8 &, 783 \\
KaiserMeyer Ölçek & Güve- &, 828 \\
nirliliği & & \\
Bartlett's Küresellik Testi Ki- & 779,673 & \\
Kare & & \\
Sd & 21 & \\
P Değeri &, 000 & \\
\hline
\end{tabular}


Doğrulayıcı faktör analizi sonucunda psikolojik sahiplenme ölçeğinin genel Cronbach's Alpha değerlerinin ,785 (KMO: ,828; Ki-Kare: 779,673; sd: 21; p:,000) olduğu belirlenmiştir. Sosyal bilimler açısından araştırmada kullanılan iki ölçeğin yeterli düzeyde geçerlilik düzeyine sahiptir.

Tablo 12. Doğrulayıcı Faktör Analizi Sonucunda Uyum İyiliği Değerleri

\begin{tabular}{lccccccccc}
\hline Değişkenler & \multirow{2}{*}{$\mathrm{X}^{2}$} & $\mathrm{f}$ & $\begin{array}{l}\mathrm{CMIN} / \\
\mathrm{DF} \leq 5\end{array}$ & $\begin{array}{c}\text { GFI } \\
\geq .85\end{array}$ & $\begin{array}{l}\text { AGFI } \\
\geq .80\end{array}$ & $\begin{array}{c}\text { CFI } \\
\geq .90\end{array}$ & $\begin{array}{c}\text { NFI } \\
\geq .90\end{array}$ & $\begin{array}{l}\text { TLI } \\
\geq .90\end{array}$ & $\begin{array}{l}\text { RMSEA } \\
\leq .08\end{array}$ \\
\hline $\begin{array}{l}\text { Örgütsel } \\
\begin{array}{l}\text { Destek } \\
\text { Psikolojik }\end{array}\end{array}$ & \multirow{2}{*}{16,70} & 1 & 2,341 &, 981 &, 938 &, 975 &, 959 &, 937 &, 064 \\
Sahiplenme & 29,841 & 2 & 2,487 &, 975 &, 943 &, 977 &, 962 &, 959 &, 068 \\
\hline
\end{tabular}

Not: Uyum iyiliği değer aralıkları "kabul edilebilir" standartlara göre düzenlenmiştir.

Tablo 12'de görüldüğü gibi ölçeklerin uyum iyilik değerleri kabul edilebilir değerlerdedir.

\section{Korelasyon Analizi ve Sonuçlan}

Araştırmamızın birinci hipotezini test edebilmek için korelasyonu analizi yapılmış ve sonuçlar Tablo 13'te sunulmuştur.

Tablo 13'de gösterilen korelasyon analizi sonuçlarına göre; örgütsel desteğin alt bileşenlerinden olan "iş ile ilgili destek" bileşeni ile psikolojik sahiplenme arasında $(\mathrm{r}=-, 393, \mathrm{p}<0,00)$ orta düzeyde, negatif yönlü anlamlı bir ilişki olduğu görülmektedir. Aynı şekilde örgütsel desteğin alt bileşenlerinden biri olan "duygusal destek" bileşeni ile psikolojik sahiplenme arasında $(\mathrm{r}=-$,390, $\mathrm{p}<0,00)$ orta düzeyde, negatif yönlü anlamlı bir ilişki olduğu belirlenmiştir.

Tablo 13. Değişkenler Arasındaki Korelasyon Analizi Bulguları

\begin{tabular}{|c|c|c|c|c|c|}
\hline \multicolumn{3}{|c|}{ Değişkenler/Alt Boyutlar } & \multirow[t]{2}{*}{ İş ile İlgili Destek } & \multirow[t]{2}{*}{ Duygusal Destek } & \multirow{2}{*}{$\begin{array}{l}\text { Psikolojik } \\
\text { Sahiplenme }\end{array}$} \\
\hline & İş ile İlgili & PearsonCorr. & & & \\
\hline Örgütsel & Destek & Sig.(2-tailed) & & & \\
\hline \multirow[t]{2}{*}{ Destek } & Duygusal & PearsonCorr. &, $440^{* *}$ & 1 & \\
\hline & Destek & Sig.(2-tailed) & ,000 & & \\
\hline \multirow{2}{*}{\multicolumn{2}{|c|}{$\begin{array}{l}\text { Psikolojik } \\
\text { Sahiplenme }\end{array}$}} & PearsonCorr. &,$- 393^{* *}$ &,$- 390^{* *}$ & 1 \\
\hline & & Sig.(2-tailed) & ,000 &, 000 & \\
\hline
\end{tabular}

${ }^{* *} 0.01$ seviyesinde korelasyon (2 kuyruklu) 
Tablo 13'te gösterildiği gibi, algılanan örgütsel destek ile psikolojik sahiplenme algısı arasında negatif yönlü bir ilişki söz konusu olduğu, bu nedenle örgütsel destek davranışlarının az olduğu durumlarda psikolojik sahiplenme algısına yönelik düşüncelerinde olumsuz yönde olabileceği söylenebilir. Bu sonuçlardan hareketle "Örgütsel destek algısı ve alt bileşenleri ile psikolojik sahiplenme arasında pozitif yönlü bir ilişki vardır" şeklinde oluşturulan (H1) reddedilmiştir.

\section{Regresyon Analizi ve Sonuçlan}

Algılanan örgütsel desteğin, psikolojik sahiplenme üzerindeki etkisi basit regresyon analizi yardımıyla incelenmiş ve sonuçları Tablo 14 'te verilmiştir. Bu bağlamda bağımlı değişken olan psikolojik sahiplenme $\%, 23^{\prime}$ lük bir oranda bağımsız değişken; örgütsel destek tarafından açıklanmaktadır. Diğer taraftan, algilanan örgütsel desteğin psikolojik sahiplenme üzerinde negatif etkisi $(\beta=-, 473 ; p<0,01)$ olduğu belirlenmiştir.

\section{Tablo 14. Regresyon Analizi Sonuçları}

\begin{tabular}{lllllll}
\hline $\begin{array}{l}\text { Psikolojik Sahiplenme } \\
\text { Bağımsız değişken }\end{array}$ & Beta & $\mathrm{t}$ değeri & Pdeğeri & $\Delta \mathrm{R}^{2}$ & $\mathrm{~F}$ & Sig. \\
\hline $\begin{array}{l}\text { Örgütsel } \\
\text { Destek(genel) }\end{array}$ &, 473 & 9,559 &, 000 &, 224 & 91,374 &, 000 \\
\hline
\end{tabular}

Algılanan örgütsel desteğin alt boyutlarının, psikolojik sahiplenme üzerindeki etkisini belirlemek üzere yapılan regresyon analizi sonuçları Tablo 14'de verilmiştir. Bağımlı değişken olan psikolojik sahiplenme $\%, 21$ 'lik bir oranda bağımsız değişken; işle ilgili destek ve duygusal destek tarafından açıklanmaktadır. Ayrıca tabloya göre, işle ilgili destek $(\beta=-, 270$; $\mathrm{p}<0,01)$ ve duygusal destek $(\beta=, 288$; $\mathrm{p}<0,01)$ psikolojik sahiplenme değişkeni üzerinde negatif etkiye sahiptirler. Bu sonuç neticesinde araştırmanın ikinci hipotezi (H2: Örgütsel destek ve alt bileşenlerinin psikolojik sahiplenme üzerinde pozitif yönde bir etkisi vardır) reddedilmiştir. 
Tablo 15.Regresyon Analizi Sonuçları

\begin{tabular}{|c|c|c|c|c|c|c|}
\hline \multirow[b]{3}{*}{ Bağımsız Değişkenler } & \multicolumn{6}{|c|}{ Psikolojik Sahiplenme } \\
\hline & \multicolumn{3}{|c|}{ Model 1} & \multicolumn{3}{|c|}{ Model 2} \\
\hline & $B$ & $\mathrm{~T}$ & $\mathrm{P}$ & $B$ & $\mathrm{~T}$ & $\mathrm{P}$ \\
\hline İş ile İlgili Destek &,- 397 & $-7,696$ &, $000^{* *}$ &,- 270 & $-4,3896$ &, $000^{* *}$ \\
\hline \multirow[t]{4}{*}{ Duygusal Destek } & & & &,- 288 & $-5,210$ &, $000^{* *}$ \\
\hline & \multirow{3}{*}{\multicolumn{3}{|c|}{$\begin{array}{l}F=59,228 \\
R^{2}=, 157 \Delta R^{2}=, 155\end{array}$}} & $\mathrm{~F}=$ & & \multirow[t]{3}{*}{45,630} \\
\hline & & & & $\mathrm{R}^{2}=, 22$ & & \\
\hline & & & & $\Delta \mathrm{R}^{2}=$ & & \\
\hline
\end{tabular}

$\left({ }^{* *} p<0,01,{ }^{*} p<0,05, N=150\right)$

Bu çalışma da algılanan örgütsel destek ve psikolojik sahiplenme konuları üzerinde durulmuştur. Çalışmanın iki amacı vardır. Birincisi çalışanların örgütsel destek algıları ile psikolojik sahiplenme arasındaki ilişkiyi ortaya koymak, diğeri ise, algilanan örgütsel desteğin psikolojik sahiplenme üzerindeki etkisini belirlemektir. Bu bağlamda bir alan araştırması yapılmış, veriler toplanmış ve literatürden yola çıkılarak oluşturulan hipotezler test edilmiştir. Çalışmada elde edilen sonuçlar aşağıda tartışılmıştır.

Araştırmada ele alınan ilk konu örgütsel destek ile psikolojik sahiplenme arasındaki ilişkidir. Çalışmada her ne kadar pozitif bir ilişki öngörülse de, istatistiksel analizler sonucunda iki değişken arasından negatifi bir ilişki olduğu belirlenmiş ve bunun sonuncunda birinci hipotezimiz (H1: Örgütsel destek ile psikolojik sahiplenme ve alt bileşenleri arasında pozitif yönlü bir ilişki vardır) reddedilmiştir. Analizler sonucunda, psikolojik sahiplenme ile örgütsel desteğin alt bileşenleri (iş ile ilgili destek ve duygusal destek) arasında, orta düzeyde negatif yönlü anlamlı bir korelasyon olduğu bulunmuştur. Bu sonuç, çalışanlara örgütsel desteğin az olduğu durumlarda, psikolojik sahiplenmenin de az olacağını ifade etmektedir. Elde edilene bu sonuç sosyal mübadele teorisi ile örtüşmektedir. Sosyal mübadele teorisi (Blau, 1964), taraflar arasında sosyal mübadeleyi ve istikrarlılı̆̆ı açıklayan bir teoridir. Tarafların davranışlarını karşılıklı ve birbirine bağlı olarak geliştiğini ifade etmektedir. Karşılıklı olumlu veya olumsuz davranışlar birbirleri nezdinde karşılık bulacaktır. Bu çalışmada çalışanların algıları, örgütsel desteğin yeterli olmadığını ve buna paralel olarak psikolojik sahiplenmede azdır. Elde edilen bu sonuçlardan yola çıkarak, örgütlerde psikolojik sahiplenmenin artmasın istiyorsak örgütsel desteğin de artırılmasına çalışmak gerekmektedir. Örneğin yöneticilerin çalışanların emek ve 
gayretlerini fark etmesi ve onların şikâyetlerini önemsemesi gibi çeşitli rolleri gerçekleştirmeleri gerekmektedir. Aksi takdirde örgütsel desteğin az ve yetersiz olduğu durumlarda psikolojik sahipleneninde az ve yetersiz olacağı yada olmayacağı aşikâr olacaktır.

Araştırmada elde edilen diğer bir bulguda ikinci hipotezimizin aksine (H2: Örgütsel desteğin alt bileşenlerinin psikolojik sahiplenme üzerinde pozitif yönde bir etkisi vardır), örgütsel desteğin ve alt bileşenlerinin psikolojik sahiplenme üzerinde negatif etkilerinin bulunmuş olmasıdır. Bu sonuç çalışmada oluşturulan hipotezin aksine bir sonuçtur. Analiz sonuçları göstermektedir ki, örgütsel destek ve bileşenleri (işle ilgili destek ve duygusal destek) çalışanların psikolojik sahiplenme algıları üzerinde negatif etkiye sahiptir. Çalışanların örgütsel destek konusundaki algılarının az ve yetersiz olması onların psikolojik sahiplenme algılarını negatif yönde etkilediklerini söyleyebiliriz.

Araştırma sonuçları genel olarak değerlendirildiğinde, çalışanların örgütlerini psikolojik açıdan sahiplenmeleri için, örgütlerin çalışanlarına vereceği desteğin çok önemli olduğu görülmektedir Örgütler, çalışanlarının tüm bilgi, tecrübe ve enerjilerini ortaya çıkarmak istiyorlarsa onları her açıdan desteklemeli, önemsemeli ve değer vermelidirler. Örgütlerin çalışanlarına verdikleri destekler azaldıkça, çalışanların örgütü psikolojik sahiplenmeyeceği ve bu azalmaya paralel olarak psikolojik sahiplenmenin de azalacağını söyleyebiliriz.

Çalışmada daha önce literatürde ele alınmamış olan örgütsel destek ve psikolojik sahiplenme ilişki ve etkilerinin ele alınmış olması bu araştırmayı diğer çalışmalardan kısmen farklı kılmaktadır. Araştırmanın iki önemli değişken arasındaki ilişkiyi ve etkiyi ele alması açısından bundan sonraki çalışmalara katkı sağlayacağı düşünülmektedir. Bundan sonra yapılacak çalışmalarda örgütsel destek ile psikolojik sahiplenme kavramlarını literatürdeki başka ilişkili kavramlarla birlikte ele alarak ilgili yazına büyük katkıları olabilir. 


\title{
EXTENDED ABSTRACT
}

\section{The Effect of Perceived Organizational Support on Psychological Ownership}

\author{
Gül Çıkmaz - Salih Yeşil \\ Hasan Kalyoncu University, Kahramanmaraş Sütçü İmam University
}

This study focuses on and investigates the organizational support and psychological ownership perception. The purpose of this study is to investigate whether organizational support has an effect on psychological ownership perception.

In general, organizational support has been studied with respect to "promotion, reward, organizational politics, performance, and justice etc." Yet till now and to our knowledge, no study has been conducted with regard to the relationship between organizational support and psychological ownership. Having being considered the literature under study, there have been studies that looked at the consequences of psychological ownership (Van Dyne and Pierce, 2004), the studies similar to our study has been very limited (Ötken, 2015, p.115). For this reason, to investigate these two important concepts, to look at the relationship between two concepts are very important to better understand concepts and contribute to the related literatures.

The first concept that needs to be defined and outlined to better understand the research objectives is the perceived organizational support. The organizational support has become an important concept during 1980s. Eisenberger (1986) defined organization support as valuing welfare, the work and participation of employees by the organization employees work for. Based on the social exchange, Blau (1964) argued that when a person does a good thing to another person, this act is result of an expectation that person has from the other person (Coyle-Shapiro and Conway, 2005, p.775). Blau (1964) argued that there has been a undefined expectations between employees and the organizations and when these expectation were unfulfilled, there would be negative consequences. (Coyle-Shapiro and Conway, 2005, p.777). Previous studies showed that perceived organizational support is feeling of employees toward how organization value 
the the participation of the employees, give importance to the happiness of the employees; meet the needs of employees (Kerse and Karabey, 2017, p.379). The perception of employees regarding organizational support may have an effect on the attitude of employees toward an organization. The perception of employees with regard to being supported by the organizations make the employees feel better. Within this realm, it is important for the employees to feel supported by the organization. The support is very important for both employees and organizations (Giray and Şahin, 2013, p.2).

The other important concept of this study is psychological ownership. It is defined as a mental situation and a situation where individual feel ownership of an organization. The core of psychological ownership is the feeling of ownership and to be connected to an object or a thing (Pare, Sicotte and Jacque 2006, s.198), the thinking of an object, asset, or idea as "mine" and "ours" (Furby, 1991, p. 458). Pierce, Kostovave Dirks (2001), defined psychological ownership as attitude toward both emotional and cognitive elements. Psychological ownership results from three reasons. First reason is to present opportunities that cause employees to feel more satisfied (Pierce, et al., 2003, p.90). Another reason is that employees has become a part of the organization which they feel ownership in order to define themselves (McIntyre, Srivastava and Fuller, 2009, s.384). The last reason that causes psychological ownership is desire of employees to find a place and feel as if they were at home in an organization (White, 1959).

When considering the time that employees spent in their organizations, it has become normal that they feel like at home and their living place would satisfy their needs. The perception of psychological ownerships could increase when these three factors that explained above are being met (Ötken, 2015, p.118). The employees who have the feeling of ownership toward their organization may reflect higher performance. The employees who have the organizational ownership are likely to experience a decrease in absence, being late and intent to leave the job (Mathieu and Zajac, 1990, p.187). According to the results of the previous studies, several studies showed that psychological ownership resulted from the organizational support. 
The study involved a field research and a total of 326 employees working in the SME in Gaziantep comprised the sample of this study. Data was collected through survey method and subsequently collected data were statically analyzed by using SPSS 21.0. According to the findings, there was a negative relationship between organizational support and psychological ownership perceptions. In addition, perceived organizational support had a negative effect on psychological ownership. The results were important to reflect upon the relationship between organizational support and psychological ownership perception. In this study where the effects of organizational support perceptions on psychological ownership were examined, it was seen that negative perceptions in organizational support behaviors could affect perceptions of psychological ownership negatively. The findings were discussed from the perspectives of both theory and practice.

\section{Kaynakça / References}

Bayram, N. (2004). Sosyal Bilimlerde Spss İle Veri Analizi. Bursa: Ezgi Kitabevi. Blau, P. M. (1964). Exchange and Power in Social Life. New York: Wiley.

Coyle-Shapiro, J. A.-M., ve Conway, N. (2005). Exchange relationships: examining psychological contracts and perceived organizational support. Journal of Applied Psychology, 90(4), 774-781.

Çakır, Ö. (2001). İşe bağhllk olgusu ve etkileyen faktörler. Ankara: Seçkin Yayıncllı. Eisenberger, R., Huntington, R., Hutchison, S., ve Sowa, D. (1986). Perceived organizational support. Journal of Applied Psychology, 71, 500-507.

Furby, L. (1991). Understanding the psychology of possession and ownership: a personal memoir and appraisal of. Journal of Social Behavior and Personality, 6(6), 457-463.

George, J. M. (1989). Mood and absence. Journal of Applied Psychology, 317-324.

George, J. M., ve Brief, A. (1992). Feeling good-doing good: a conceptual analysis of the mood at work-organizational spontaneity relationship. Psychological Bulletin, 112(2), 319-329.

Giray, M. D., ve Şahin, D. (2013). Algılanan örgütsel, yönetici ve çalışma arkadaşları desteği ölçekleri: geçerlik ve güvenirlik çalışması. Türk Psikoloji Yazıları, 15(30), 1-9. 
Hellman, C. M., Fuqua, D., ve Worley, J. (2006). A reliability generalization study on the survey of perceived organizational support: the effects of mean age and number of items on score reliability. Educational and Psychological Measurement, 66(4), 631-642.

Kalaycı, Ş. (2014). SPSS uygulamalı çok değişkenli istatistik teknikleri. Ankara: Asil Yayın Evi

Jeswani, S., ve Dave, S. (2012). A study on the impact of predictors of psychological ownership on turnover intention among faculty members. IJEMR, 2(2). - Online - ISSN 2249 - 2585 - Print - ISSN 2249 $-8672$

Kerse, G., ve Karabey, C. (2017). Algilanan örgütsel desteğin örgütsel özdeşleşmeye etkisi: örgütsel sinizmin aracı rolü. MANAS Sosyal Araştırmalar Dergisi, 6(4), 375-398.

Mathieu, J., ve Zajac, D. (1990). A review and meta-analysisof the antecedents, correlates and consequences of organizational commitment. Psychological Bulletin, 171-194.

McIntyre, N., Srivastava, A., ve Fuller, J. A. (2009). The relationship of locus of control and motives with psychological ownership in organizations. Journal of Managerial Issues, 21(13), 383-411.

Meyer, J. P., ve Allen, N. (1997). Commitment in the Workplace: Theory, Research, and Application. London: Sage Publication.

Meyer, J. P., ve Allen, N. J. (1991). A three-component conceptualization of organizational commitment. Human Resource Management Review, $1(1), 61-89$.

Ötken, A. B. (2015). Algılanan örgütsel destek ve psikolojik sahiplenme arasındaki ilişki ve bu ilişkide örgütsel adaletin rolü. Hacettepe Üniversitesi İktisadi ve İdari Bilimler Fakültesi Dergisi, 33(2), 113-140.

Pare, G., Sicotte, C., ve Jacque, H. (2006). The effects of creating psychological ownership on physicians' acceptance of clinical information systems. Journal of the American Medical Informatics Association, 13(2), 197-205.

Pierce, J. L., Kostova, T., ve Dirks, K. (2001). Toward a theory of psychological ownership in organizations. Academy of Management Review, 26(2), 298-310.

Pierce, J. L., Kostova, T., ve Dirks, K. (2003). The state of psychological ownership: integrating and extending a century of research. Review of General Psychology, 7(1), 84-107. 
Rhoades, L., ve Eisenberger, R. (2002). Perceived organizational support: a review of the literature. Journal of Applied Psychology, 87(4), 698-714.

Van Dyne, L., ve Pierce, J. L. (2004). Psychological ownership and feelings of possession: three field studies sredicting employee attitudes and organizational citizenship behavior. Journal of Organizational Behavior, 25(4), 439-459.

White, R. W. (1959). "Motivation reconsidered: the concept of competence. Psychological Review, 66(5), 297-330.

\section{Kaynakça Bilgisi / Citation Information}

Çıkmaz, G. ve Yeşil, S. (2020). Çalışanların algıladıkları örgütsel desteğin psikolojik sahiplenme üzerine etkisi. OPUS-Uluslararası Toplum Araştırmaları Dergisi, 15(22), 1234-1254. DOI: 10.26466/opus.658193 